\title{
Evaluation of Biocompatibility of Different Membrane Surfaces Using Unrestricted Somatic Stem Cells
}

\author{
LARA SCHORN ${ }^{1}$, JÖRG HANDSCHEL ${ }^{2}$, JULIAN LOMMEN $^{1}$, FELIX PAULSSEN VON BECK ${ }^{3}$, \\ RITA DEPPRICH ${ }^{1}$, NORBERT KÜBLER ${ }^{1}$ and HENRIK HOLTMANN ${ }^{4}$ \\ ${ }^{1}$ Department of Oral-, Maxillo- and Plastic Facial Surgery, \\ Heinrich-Heine-University and University Hospital Duesseldorf, Duesseldorf, Germany; \\ ${ }^{2}$ Klinik und Praxisgemeinschaft am Kaiserteich, Düsseldorf, Germany; \\ ${ }^{3}$ Department of Oral-, Maxillo- and Plastic Facial Surgery, Malteser Krankenhaus, \\ St. Josefshospital Uerdingen, Krefeld-Uerdingen, Germany; \\ ${ }^{4}$ Department of Oral-, Maxillo- and Plastic Facial Surgery, \\ Malteser Krankenhaus St. Johannes-Stift, Duisburg, Germany
}

\begin{abstract}
Background/Aim: Results of Guided Bone Regeneration (GBR) primarily depend on the membrane used. The aim of this study was to compare biocompatibility of different absorbable and non-absorbable membranes by using unrestricted somatic stem cells (USSCs) as an indicator for biocompatibility. Materials and Methods: Five absorbable membranes (Bio-Gide ${ }^{\circledR}$, RESODONT $^{\circledR}$, GENTAFOIL resorb ${ }^{\circledR}$, BioMend ${ }^{\circledR}$ and BioMend ${ }^{\circledR}$ Extend $\left.^{T M}\right)$ and one non-absorbable alternative (GORE-TEX $\left.X^{\circledR}\right)$ were colonized with USSCs. After 24 h, 3 days and 7 days, cell proliferation, cell viability, and cytotoxicity were assessed. Moreover, cell morphology was evaluated by electron microscopy. Results: Significantly higher cell proliferation and cell viability rates were observed in Bio-Gide ${ }^{\circledR}$ and RESODONT ${ }^{\circledR}$ membranes. Cell toxicity was highest on GENTA-FOIL resorb ${ }^{\circledR}$ membranes. The electron microscopical assessment showed a better cell attachment on porous surfaced membranes. Conclusion: This study shows that USSCs can be used for assessments of biocompatibility, and that absorbable membranes with collagenous composition and porous structure tend to positively impact biocompatibility and enhance cell proliferation.
\end{abstract}

This article is freely accessible online.

Correspondence to: Prof. Dr. Dr. Jörg Handschel, Klinik und Praxisgemeinschaft am Kaiserteich, Reichsstraße 59, 40217 Düsseldorf, Germany. Tel: +49 021122050220, Fax: +49 02112205022499, e-mail: handschel@klinikamkaiserteich.de

Key Words: Biocompatibility, unrestricted somatic stem cells (USSCs), guided bone regeneration (GBR), membranes.
Bony defects involving the head and face often result not only in limited functionality, but also present esthetic deficiencies reducing patients' quality of life (1). Depending on defect size, different covering techniques are applied. In cases of greater bony defects, augmentative procedures become necessary (2). Current gold standards for bone augmentation are autologous bone grafts mainly retrieved from the scapula, the fibular bone, and the iliac crest (3). Disadvantages are donor site morbidity and limited availability (4). Alternatives to autologous bone grafts present various methods of tissue engineering and guided bone regeneration (GBR) $(5,6)$. GBR has been described in research over the last 20 years (7-10). In GBR, occlusive membranes are used to prevent soft tissue ingrowth into the bone, allowing osteogenic cells originating from the adjacent bone to immigrate the restoration site (5). Results of GBR primarily depend on the membrane used (11). Ideally the membrane material should be biocompatible, provide a way for revascularization of the defect area, and allow nutrition of target cells (12). Nowadays, mainly absorbable membranes are used (13), and their indications have been expanded to periodontal flap surgery (14) and third molar extraction (15), providing appealing results. Nevertheless, their clinical application is still restricted due to high costs, difficult clinical handling, infection, and collapse of membranes (16).

The aim of this study was to compare biocompatibility of different absorbable and non-absorbable membranes. As indicator for biocompatibility unrestricted somatic stem cells (USSCs) were used. USSCs retrieved from the umbilical cord can be cultivated without losing their potential of pluripotent differentiation (17). They seem to hold an epigenetic state in between a terminally differentiated cell type and that of embryonic stem cells (18). Under certain 
in vivo $33: 1447-1454(2019)$

Table I. Characteristics of the different membranes (Bio-Gide ${ }^{\circledR}$, RESODONT $^{\circledR}$, GENTA-FOIL resorb ${ }^{\circledR}$, BioMend $^{\circledR}$, BioMend ${ }^{\circledR}$ Extend $^{T M}$ und GORE$\left.T E X^{\circledR}\right)$.

\begin{tabular}{|c|c|c|c|c|c|c|c|}
\hline Product name & Producer & Origin & $\begin{array}{l}\text { Collagen } \\
\text { type }\end{array}$ & $\begin{array}{l}\text { Cross- } \\
\text { linking }\end{array}$ & Sterilization & Membrane sizes & Specialities \\
\hline GORE-TEX $^{\circledR}$ & $\begin{array}{l}\text { W.L. Gore \& Associates, } \\
\text { Inc. (Flagstaff, AZ, USA) }\end{array}$ & $\begin{array}{l}\text { Synthetic } \\
\text { (ePTFE) }\end{array}$ & - & - & $\begin{array}{l}\text { Ethylenoxide- } \\
\text { Gas }\end{array}$ & $\begin{array}{c}\text { Different sizes } \\
\text { and shapes from } \\
13 \times 18 \text { to } \\
28 \times 37 \mathrm{~mm}\end{array}$ & $\begin{array}{c}\text { Titan supported membrane, } \\
\text { non-absorbable, often } \\
\text { used in hard and } \\
\text { soft tissue regeneration }\end{array}$ \\
\hline $\begin{array}{l}\text { BioMend }{ }^{\circledR} \\
\text { Extend }^{\mathrm{TM}}\end{array}$ & $\begin{array}{l}\text { Zimmer Dental GmbH } \\
\text { (Freiburg, Germany) }\end{array}$ & Bovine & Type I & $\begin{array}{l}\text { Gluta- } \\
\text { raldehyde }\end{array}$ & $\begin{array}{l}\text { Ethylenoxide- } \\
\text { Gas }\end{array}$ & $\begin{array}{c}15 \times 20,20 \times 30 \\
\text { and } 30 \times 40 \mathrm{~mm}\end{array}$ & $\begin{array}{l}\text { Small pore sizes }(4 \mathrm{~nm}) \text {, } \\
\text { keeps epithelial tissue out, } \\
\text { integrates well to the } \\
\text { surrounding tissues }\end{array}$ \\
\hline BioMend $^{\circledR}$ & $\begin{array}{l}\text { Zimmer Dental GmbH } \\
\text { (Freiburg, Germany) }\end{array}$ & Bovine & Type I & $\begin{array}{l}\text { Gluta- } \\
\text { raldehyde }\end{array}$ & $\begin{array}{l}\text { Ethylenoxide- } \\
\text { Gas }\end{array}$ & $\begin{array}{l}15 \times 20,20 \times 30 \\
\text { and } 30 \times 40 \mathrm{~mm}\end{array}$ & $\begin{array}{l}\text { Small pore sizes }(4 \mathrm{~nm}) \text {, } \\
\text { keeps epithelial } \\
\text { tissue out, integrates well } \\
\text { to the surrounding tissues }\end{array}$ \\
\hline $\begin{array}{l}\text { GENTA-FOIL } \\
\text { resorb }^{\circledR}\end{array}$ & $\begin{array}{c}\text { Resorba } \\
\text { Wundversorgung } \\
\text { GmbH \& Co. KG } \\
\text { (Nuernberg, Germany) }\end{array}$ & Equine & Type I & None & $\begin{array}{l}\text { Ethylenoxide- } \\
\text { Gas }\end{array}$ & $\begin{array}{l}25 \times 25 \text { and } \\
25 \times 50 \mathrm{~mm}\end{array}$ & $\begin{array}{l}\text { Contains gemtamycin, after } \\
\text { being placed into } \mathrm{NaCl} \text { or } \\
\text { into the oral cavity } \\
\text { dissolves and becomes } \\
\text { easily shapeable. }\end{array}$ \\
\hline RESODONT $^{\circledR}$ & $\begin{array}{c}\text { Resorba } \\
\text { Wundversorgung } \\
\text { GmbH \& Co. KG } \\
\text { (Nuernberg, Germany) }\end{array}$ & Equine & Type I & None & $\begin{array}{l}\text { Ethylenoxide- } \\
\text { Gas }\end{array}$ & $\begin{array}{l}30 \times 35 \text { and } \\
30 \times 70 \mathrm{~mm}\end{array}$ & $\begin{array}{l}\text { Usable on both sides, keeps } \\
\text { its shape even when wet, } \\
\text { similar to human tissue }\end{array}$ \\
\hline Bio-Gide ${ }^{\circledR}$ & $\begin{array}{c}\text { Geistlich Pharma AG } \\
\text { (Wolhusen, Switzerland) }\end{array}$ & Porcine & $\begin{array}{l}\text { Type I + } \\
\text { Type III }\end{array}$ & None & $\gamma$-irradiation & $\begin{array}{l}25 \times 25 \text { and } \\
30 \times 40 \mathrm{~mm}\end{array}$ & $\begin{array}{l}\text { Great similarity to human } \\
\text { tissue, osteoinductive, } \\
\text { accelerates healing process }\end{array}$ \\
\hline
\end{tabular}

conditions USSCs can be differentiated into osteoblasts, chondroblasts, adipocytes, hematopoietic, and neural cells (17). Dexamethasone, ascorbic acid, and $\beta$-glycerol phosphate (DAG) are used for differentiation into osteoblasts in vitro (19) and in vivo, as well (20).

\section{Materials and Methods}

This study was approved by the Ethics-Committee of the HeinrichHeine University Dusseldorf, Germany (No.: 3376).

All membranes used have already been tested in vivo and are approved medical products. For absorbable membranes Bio-Gide ${ }^{\circledR}$ (Geistlich Pharma AG, Wolhusen, Switzerland), RESODONT ${ }^{\circledR}$ (RESORBA Wundversorgung $\mathrm{GmbH} \& \mathrm{Co}$. KG, Nuernberg, Germany), GENTA-FOIL resorb ${ }^{\circledR}$ (RESORBA Wundversorgung GmbH \& Co. KG), BioMend ${ }^{\circledR}$ and BioMend ${ }^{\circledR}$ Extend $^{\mathrm{TM}}$ (Zimmer Dental GmbH, Freiburg, Germany) were used. As a non-absorbable alternative a (GORE-TEX ${ }^{\circledR}$ W.L. Gore \& Associates, Inc., Flagstaff, USA) membrane was tested (detailed membrane characteristics are shown in Table I).

First, the membranes were sterilized, then cut into pieces $(n=27)$ containing an area of $0.785 \mathrm{~cm}^{2}$ in order to fit the holes of a well plate. A total of 9 pieces were used per cell line per day of testing. Those 9 pieces were used for the measurement of cell proliferation $(n=5)$, the measurement of cytotoxicity and cell activity $(n=3)$, and for measurements with the raster electron microscope $(n=1)$. Because of their buoyancy in the culture medium, pieces of the
RESODONT $^{\circledR}$ - and the GENTA-FOIL resorb ${ }^{\circledR}$ membranes had to be fixed on the well plate surface. As a control a standard cell culture surface was used. All wells (either containing membranes or the control group) were filled with $610 \mu \mathrm{l}$ culture medium and placed into the incubator at $37^{\circ} \mathrm{C}, 21 \% \mathrm{O}_{2}$ and $5 \% \mathrm{CO}_{2}$ saturation.

USSCs were provided by the José Carreras stem cell bank of the University of Duesseldorf. The following cell lines were used: USSC-18 (female, Passage 8), USSC-8 (female Passage 9), USSC$8 / 17$ (male, Passage 8). To prepare the nutrient medium, $350 \mathrm{ml}$ DMEM (Dulbecco's modified eagle medium, Lonza Cologne $\mathrm{GmbH}$, Cologne, Germany), $150 \mathrm{ml}$ fetal bovine serum (FBS, PANBiotech $\mathrm{GmbH}$, Aidenbach, Germany), $5 \mathrm{ml}$ penicillin/streptomycin $(10,000 \mathrm{U} / 10,000 \mu \mathrm{g} / \mathrm{ml}$, Biochrom GmbH, Berlin, Germany), and $5 \mathrm{ml} \mathrm{L}$-glutamine $(200 \mathrm{mM}$, Biochrom $\mathrm{GmbH})$ were used. The differentiation was induced using DAG (50 $\mu \mathrm{M}$ Dexamethasone in DMEM (Sigma-Aldrich Chemie GmbH, Steinheim, Germany), $50 \mathrm{mM}$ Ascorbic acid (Sigma-Aldrich Chemie $\mathrm{GmbH}$ ) in phosphate buffered saline (PBS) and $1 \mathrm{M} \beta$-Gycerolphasphate in PBS) using a standardized protocol (20). Cells were cultivated in an incubator according to the standard protocol $\left(37^{\circ} \mathrm{C}, 21 \% \mathrm{O}_{2}\right.$ and $5 \% \mathrm{CO}_{2}$ saturation).

Every membrane was cultivated with a total of $19 \times 10^{3}$ cells for specific time intervals. After 24 h, 3 days, and 7 days representative membranes were selected, frozen and fixated for examination. The culture medium and the embedded well plates were renewed after $24 \mathrm{~h}$ and after 4 days. Cell viability was measured directly in the culture using CellTiter-Blue ${ }^{\circledR}$ Cell Viability Assay (Promega GmbH, Mannheim, Germany). Cytotoxicity was measured indirectly 


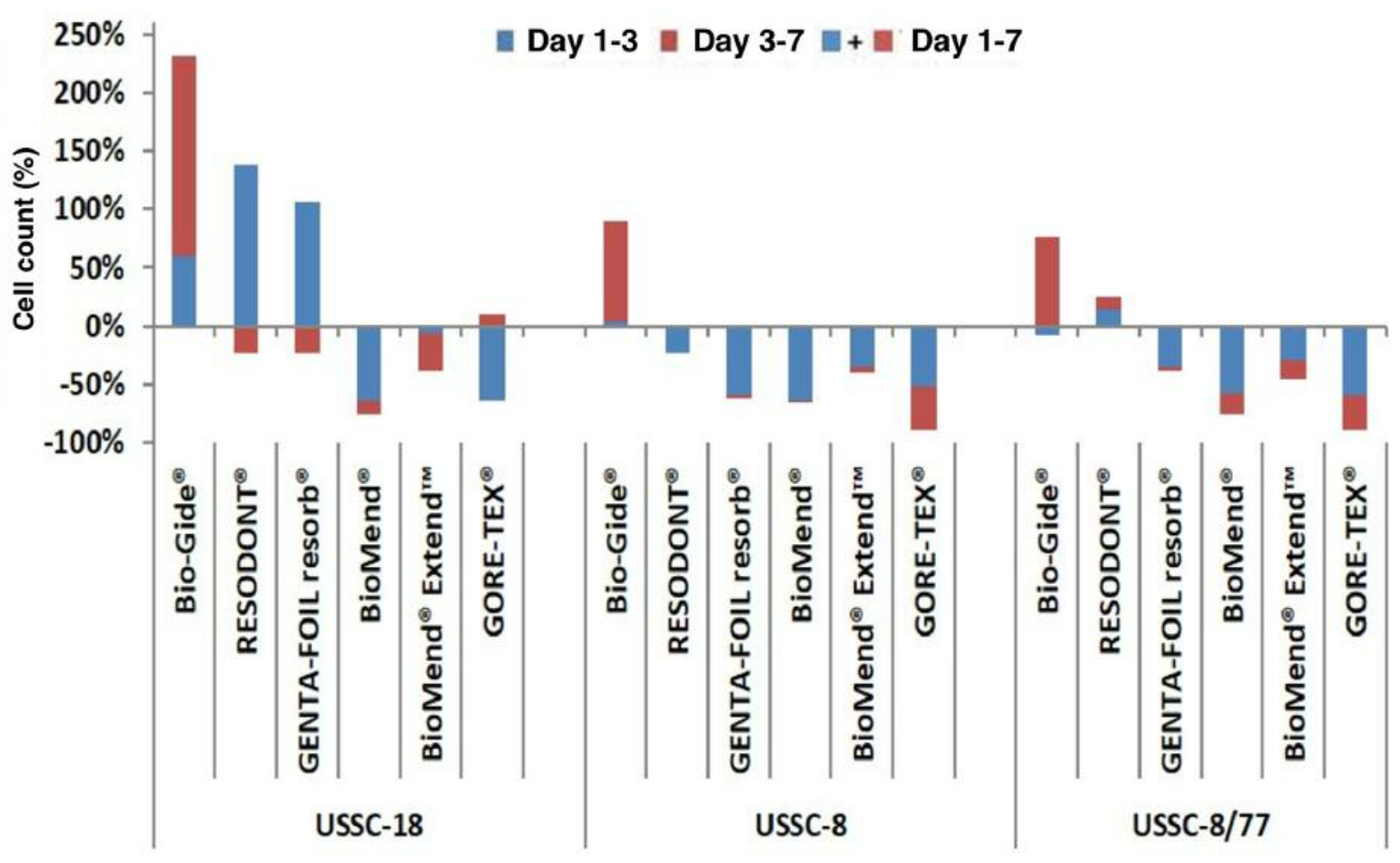

Figure 1. Attachment and proliferation of the osteogenic USSC-18, -8 and -8/77 cell lines growing on different membranes (Bio-Gide ${ }^{\circledR}$, RESODONT ${ }^{\circledR}$, GENTA-FOIL resorb ${ }^{\circledR}$, BioMend $^{\circledR}$, BioMend $^{\circledR}$ Extend $^{T M}$ und GORE-TEX ${ }^{\circledR}$ ) for 1, 3, and 7 days. $* * * p<0.0005$.

through the cell culture supernatant using CytoTox-ONE ${ }^{\text {TM }}$ Homogeneous Membrane Integrity Assays (Promega GmbH). For cell count and membrane fixation (for REM-evaluation), membranes were washed with attenuated PBS solution and frozen $\left(-80^{\circ} \mathrm{C}\right)$. Cell count was performed with the help of CyQuant ${ }^{\circledR}$ Cell Proliferation Assay Kit (Life Technologies GmbH, Darmstadt, Germany). For REM-evaluation the membranes were placed into $5 \%$ Glutardialdehydle, dried by an ascending acetone series (50\%-70\%90-100\%) and Critical Point Dryer CPD 030 (BAL-TEC GmbH, Schalksmuhle, Germany). For electrification, the membranes were sputtered using Sputter Coater 108 auto (Ted Pella, Inc., Redding, CA, USA). For evaluation a Scanning-Electron-Microscope S$3000 \mathrm{~N}$ was used.

Statistical analysis. In total 27 pieces of each membrane were examined $(n=189)$. Nine pieces were used for each cell line $(n=9)$. Five of those were used for the measurement of cytotoxicity $(n=5)$. Three were used for cell viability $(n=3)$, and one piece was used for measurements with the raster electron microscope $(n=1)$. A ShapiroWilk test was used for evaluation of normal distribution. In order to detect statistically significant differences a one-way ANOVA and the Bonferroni correction was performed as post-hoc test. Furthermore, $t$-tests were performed to find significant differences in comparison to the control group (specific membrane in comparison to the control group only). Calculations were made by the use of SPSS 21 for Mac (SPSS Inc., Chicago, IL, USA). Differences with $p<0.05$ were considered statistically significant. Data is presented as mean \pm standard deviation.

\section{Results}

The aim of this study was to evaluate biocompatibility of 6 different membrane types. Twenty-four hours after cell seeding, 7,617 $\pm 1,040$ USSC-18 cells, 5,824 \pm 425 USSC-8 cells, and $6,000 \pm 600$ USSC-8/77 cells could be found on the control standard surface. In the control wells, significantly increased proliferation was observed in all cell lines, between days 1 and $3(p>0.0005)$ and days 3 and $7(p<0.05)$.

After $24 \mathrm{~h}$, in cell line USSC-18, the RESODONT ${ }^{\circledR}$ membrane surface showed significantly more cell attachment $(3,756 \pm 336 ; p>0.0005)$ followed by the Bio-Gide ${ }^{\circledR}$ membrane $(2,715 \pm 361 ; p>0.0005)$, compared to the other membranes. Highest cell counts were found on day 7 on BioGide ${ }^{\circledR}$ membranes (USSC-18: 9,015 $\pm 1,491$ cells, USSC-8:

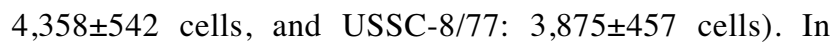
comparison to the numbers of cells on day 1 , they showed significant differences $(p>0.0005)$ in cell lines USSC-8 and USSC-8/77 on day 7 . Relative differences (\%) in cell count on the distinct membrane surfaces after 3 and 7 days in comparison to day 1 and day 3 are shown in Figure 1.

Cell viability was measured fluoroscopically (560Ex/590Em) and assessed after 1, 3 and 7 days. The control group showed significant rises in cell viability in every measurement, USSC- 


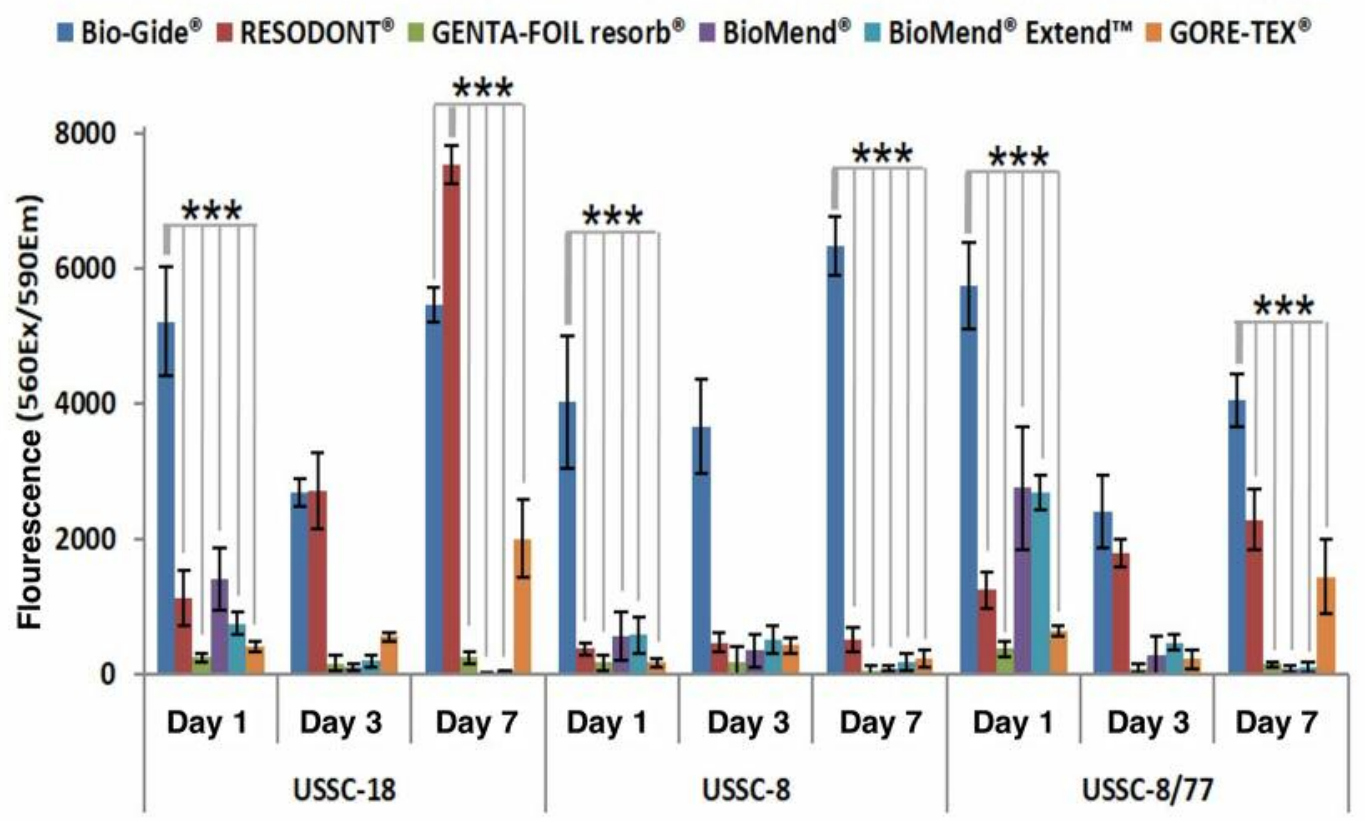

Figure 2. Viability of the osteogenic USSC-18, -8 and -8/77-cell lines growing on different membranes (Bio-Gide ${ }^{\circledR}$, RESODONT ${ }^{\circledR}$, GENTA-FOIL resorb $^{\circledR}$, BioMend $^{\circledR}$, BioMend $^{\circledR}$ Extend $^{T M}$ and GORE-TEX $\left.{ }^{\circledR}\right)$ for 1, 3, and 7 days. $* * * p<0.0005$, Fluorescence $(560 E x / 590 E m)$.

18 performed significantly better than the other two cell lines $(p<0.0005$; Day 1: USSC-18: 9,324 \pm 442 RFU, USSC-8: 7,942 \pm 447 RFU, and USSC-8/77 5,795 \pm 660 RFU; Day 7: USSC-18 17,222 \pm 395 RFU, USSC-8 14,019 \pm 457 RFU, and USSC-8/77 13,926 $\pm 910 \mathrm{RFU})$. After $24 \mathrm{~h}$, a significantly higher overall viability (in every cell line) could be observed on the Bio-Gide ${ }^{\circledR}$ membrane, in comparison to the other membranes tested $(p<0.0005)$. This viability declined on day 3 , but recovered significantly on day 7 . The membranes, on which least cell viability was observed, were the GENTA-FOIL resorb ${ }^{\circledR}$ and the GORE-TEX ${ }^{\circledR}$ (Figure 2). In terms of viability per cell after $24 \mathrm{~h}$, the greatest viability could be observed on the Bio-Gide ${ }^{\circledR}$ membrane (USSC-18: 1.92 \pm 0.51 RFU/cell, USSC-8: $1.75 \pm 0.38$ RFU/cell, USSC-8/77: 2.50 \pm 0.64 RFU/cell). On day 3 and 7, viability per cell was greatest on GORE-TEX ${ }^{\circledR}$ membranes (Day 3: USSC-18: $+2.19 \pm 0.52 \mathrm{RFU} /$ cell, USSC-8: $+5.24 \pm 1.25$ RFU/cell and USSC-8/77: $+13.67 \pm 3.32 \mathrm{RFU} /$ cell and day 7 : USSC-18: $0.60 \pm 0.30 \mathrm{RFU} / \mathrm{cell}$, USSC-8: $1.45 \pm 0.53 \mathrm{RFU} / \mathrm{cell}$, and USSC-8/77: 1.04 $\pm 0.47 \mathrm{RFU} / \mathrm{cell}$ ) (Figure 3).

In terms of cytotoxicity, only the 4 membranes with the highest proliferation/viability rates $\left(\right.$ Bio-Gide ${ }^{\circledR}$, RESODONT $^{\circledR}$, GENTA-FOIL resorb ${ }^{\circledR}$ and GORE-TEX ${ }^{\circledR}$ ) were compared to each other and to the control group. Cytotoxicity on day 3 was significantly higher in cells grown on membranes, compared to the control wells. On day 3 , the highest cytotoxicity was measured on GENTA-FOIL resorb ${ }^{\circledR}$ membranes (USSC-18: 21,613 $\pm 2,364$ RFU, USSC-8:
33,242 $\pm 2,181$ RFU, and USSC-8/77: 23,623 $\pm 1,879$ RFU, $p<0.0005$ ), while the lowest cytotoxicity was measured on GORE-TEX $^{\circledR}$ membranes (USSC-18: 15,998 $\pm 1,212$ RFU, USSC-8: 30,662 \pm 928 RFU and USSC-8/77: 19,769 $\pm 3,187$ RFU). After 7 days, in cell lines USSC-18 (9,334 \pm 1.082 RFU) and USSC-8/77 (11,192 \pm 1.352 RFU) lowest cytotoxicity rates were measured $(p<0.005)$ in the control group, whereas in cell line USSC-8 (12,959 \pm 633 RFU) highest cytotoxicity rates were measured in the control group $(p<0.005)$. In USSC-8 they were significantly higher than those on RESODONT ${ }^{\circledR}(10,991 \pm 781$ RFU), GENTA-FOIL resorb $^{\circledR}\left(11,451 \pm 364\right.$ RFU) and GORE-TEX ${ }^{\circledR}(10,526 \pm 841$ RFU) $(p<0.0005)$. In the USSC-18 cell line highest cytotoxicity was found on RESODONT $^{\circledR}$ membranes $\left(21,230 \pm 2,622\right.$ RFU) and in USSC-8/77 on GORE-TEX ${ }^{\circledR}$

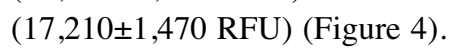

Additionally, raster electron microscope images of the cultivated membranes were compared to each other and to non-colonized membranes (Figure 5). The Bio-Gide ${ }^{\circledR}$ membrane comes with a porous side facing the defect. After $24 \mathrm{~h}$, the USSCs showed long cell extensions attaching to the collagenous fibers of the membrane. After 7 days, the cells aligned with the collagenous fibers. In comparison to the Bio-Gide ${ }^{\circledR}$, the other membranes presented a smooth surface. After $24 \mathrm{~h}$, the RESODONT ${ }^{\circledR}$ membrane surface changed and appeared spongey and porous. The USSCs showed long cell extensions attaching 

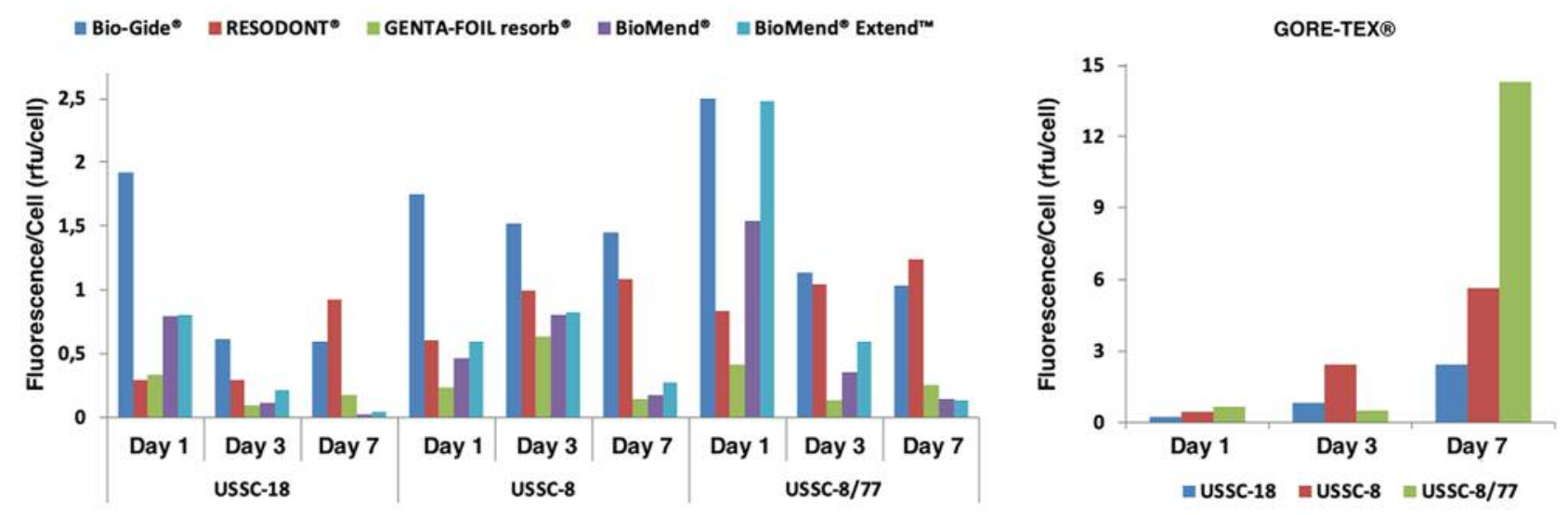

Figure 3. Relative proliferation rates of the osteogenic USSC-18, -8 and -8/77-cell lines on different membranes (Bio-Gide ${ }^{\circledR}$, RESODONT $^{\circledR}$, GENTAFOIL resorb ${ }^{\circledR}$, BioMend $^{\circledR}$, BioMend $^{\circledR}$ Extend $^{T M}$ and GORE-TEX $\left.{ }^{\circledR}\right)$ between days 1 and 3, days 3 and 7 and between days 1 and 7 in comparison to the cell count on day $1(p<0.005)$.

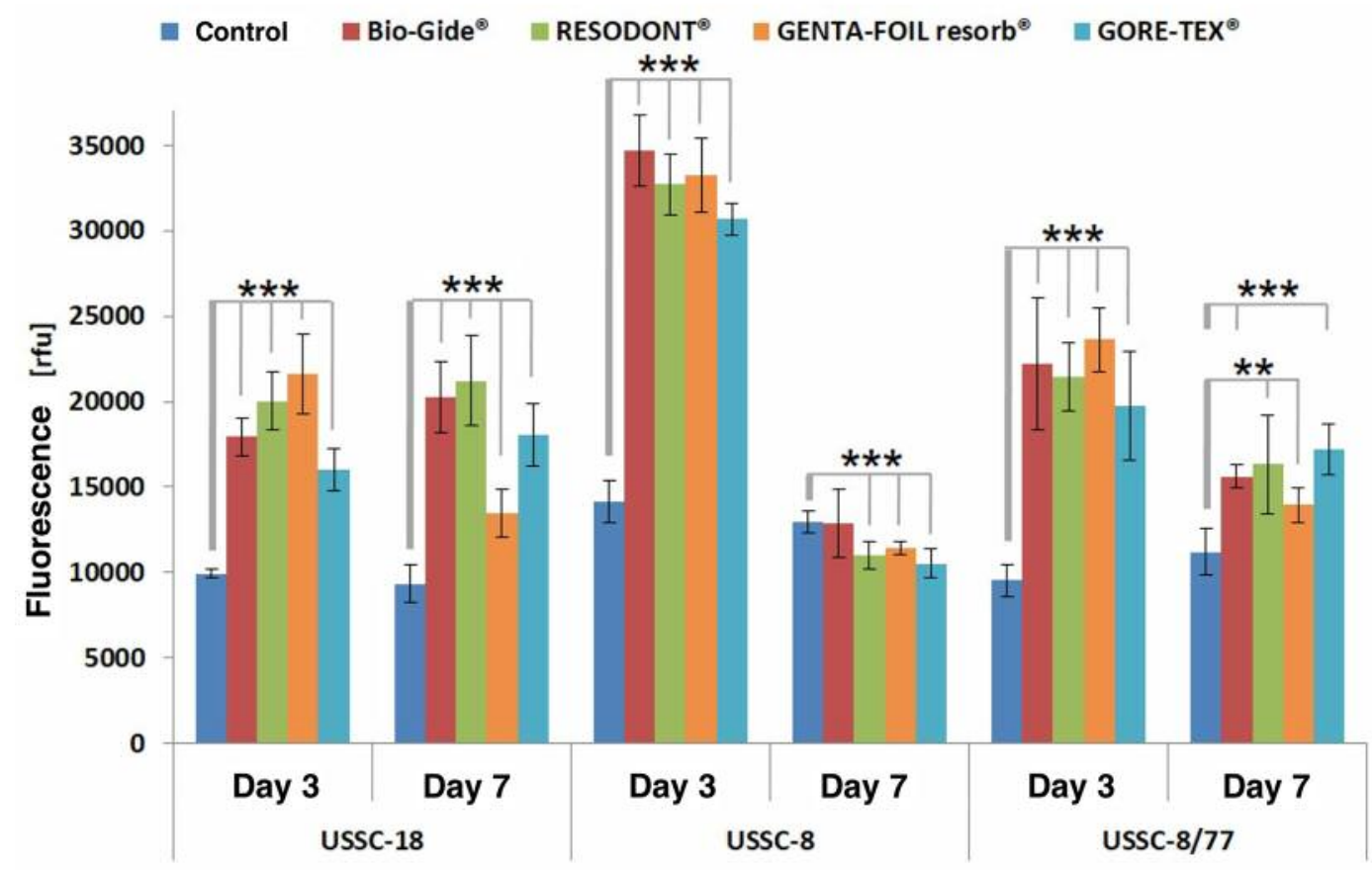

Figure 4. Cytotoxicity on a standard cell surface and on the membranes (Bio-Gide ${ }^{\circledR}$, RESODONT $^{\circledR}$, GENTA-FOIL resorb ${ }^{\circledR}$ and GORE-TEX ${ }^{\circledR}$ ) on the osteogenic differentiated USSC-18, -8 and -8/77-cell lines after days 1,3 and 7 . ***p<0.0005, **p<0.005.

to the RESODONT ${ }^{\circledR}$ membrane, similarly to Bio-Gide ${ }^{\circledR}$, while a continuous cell layer had developed after 7 days. The GENTA-FOIL resorb ${ }^{\circledR}$ membrane changed into a less porous surface after $24 \mathrm{~h}$. A few elongated USSCs with small extensions could be observed. Up to day 3, they enlarged and become radial. After 7 days, USSC appeared elongated and smaller again. BioMend ${ }^{\circledR}$ and BioMend ${ }^{\circledR}$
Extend $^{\mathrm{TM}}$ showed almost no change in membrane surface and only weakly adhering USSCs with few, short cell extensions showed after 7 days. Finally, the GORE-TEX ${ }^{\circledR}$ membrane was the only one showing collagenous polytetrafluoroethylene fibers (PTFE-Fibers). After 7 days, there was only little cell attachment and a few cell extensions could be observed. 


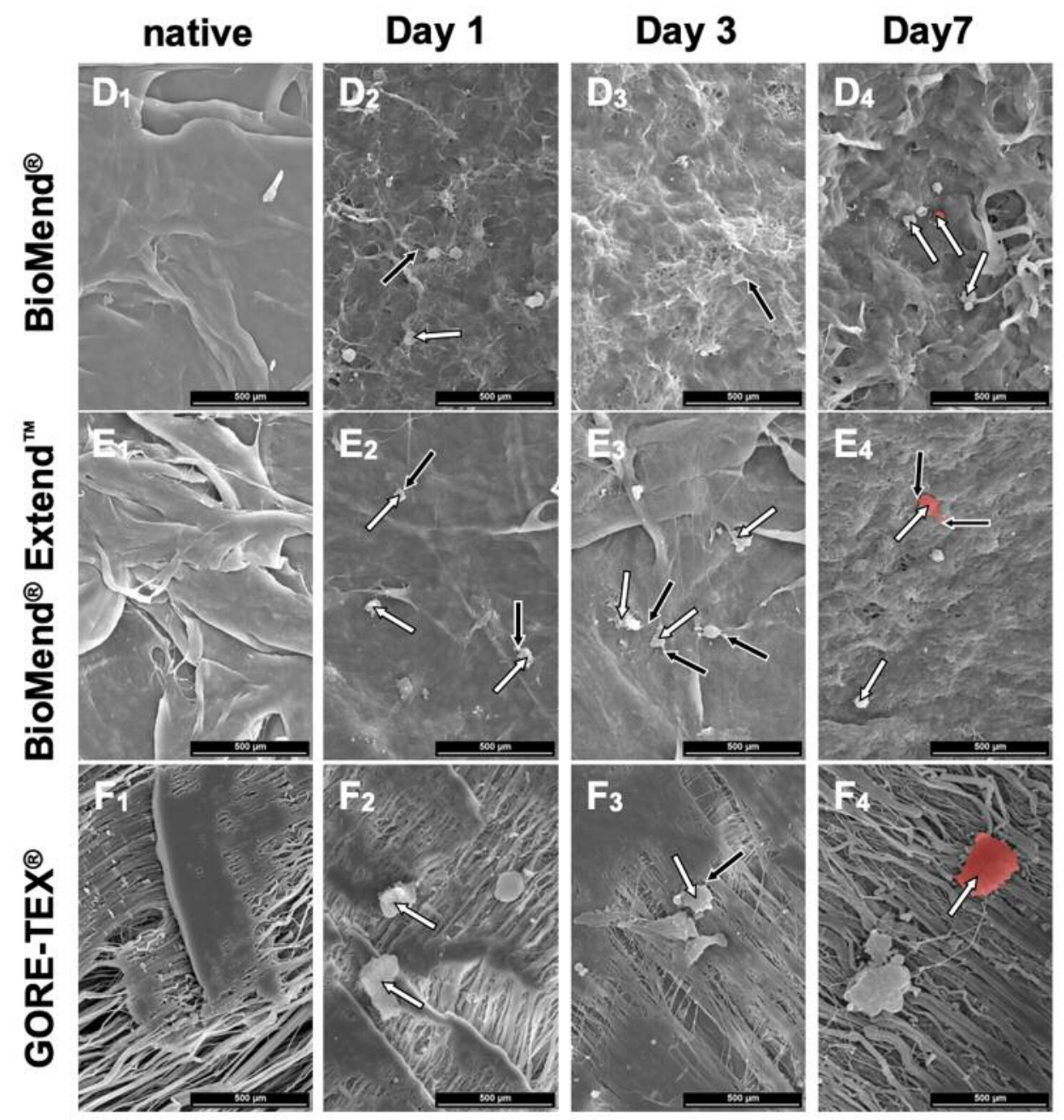

Figure 5. Raster electron microscope images of the studied membranes, native and colonized with USSC-18, for days 1, 3 and 7 (magnification $500 \times)$. For day 7, a representative cell has been marked in red. Cell structure, form, and size differed depending on the membrane surface. White arrow: cell, black arrow: cell extension.

\section{Discussion}

A recent review by Carballé-Serrano et al. (21) stated that biocompatibility is the crucial factor taken into account when choosing a membrane for guided bone regeneration. In this study the attachment, proliferation, and cell activity of osteoblast-differentiated USSCs growing on five resorbable membranes and one non-resorbable membrane were evaluated, as well as the cytotoxic effects on these cells. For cell attachment a membrane has to be biocompatible (22). In vivo cell attachment depends not only on the membrane material, but also on the location and timing of placement, together with condition and age of a patient (11). A rough membrane surface supports attachment and proliferation of osteoblasts, whereas fibroblasts tend to attach to smooth surfaces more easily $(23,24)$. The rough surfaces of the RESODONT ${ }^{\circledR}$ and Bio-Gide ${ }^{\circledR}$ membranes might be a reason for their high rates of cell attachment. Furthermore, cell proliferation was highest after $24 \mathrm{~h}$ on Bio-Gide ${ }^{\circledR}$ membranes, after 3 days on RESODONT ${ }^{\circledR}$, and after 7 days on Bio-Gide ${ }^{\circledR}$ membranes again. Proliferation and cell numbers were significantly higher than on the other membranes. This could also be due to their composition. Bio-Gide ${ }^{\circledR}$ membranes consist of a mixture of collagen type I and III, whereas the others only contain collagen type III. Therefore, collagen type I or the mixture of collagens might have a positive impact on cell proliferation. In a similar study by Rothamel et al. (25) using osteobleasts, it was demonstrated that Bio-Gide ${ }^{\circledR}$ membranes had the highest proliferation rates. In accordance with the findings of this 
study, sparsely cell proliferation rates have been reported for BioMend ${ }^{\circledR}$ membranes $(25,26)$. This might be due to the glutaraldehyde used for cross-linking in these membranes $(27,28)$. Cross-linking treatments involving glutaraldehyde or formaldehyde are included to overcome rapid membrane degradation $(12,29)$. Glutaraldahyde may also be a reason for reduced cell viability, as cell metabolic activity was significantly highest on Bio-Gide ${ }^{\circledR}$ membranes at all sample points. UV-irradiation for cross-linking might present a more compatible solution (30). On RESODONT ${ }^{\circledR}$, cell viability was significantly higher than on the other membranes. Gentamycin is added to GENTA-FOIL resorb ${ }^{\circledR}$ membranes, which might reduce cell viability in those membranes. GENTA-FOIL resorb ${ }^{\circledR}$ also showed significantly high cytotoxicity rates. In contrast, high cytotoxicity rates were found on Bio-Gide ${ }^{\circledR}$, RESODONT ${ }^{\circledR}$ and GORE-TEX ${ }^{\circledR}$ membranes as well. Osteoblasts are very sensitive to surface structures $(31,32)$. Altered surface structures might, therefore, not only result in enhanced cell proliferation and attachment, but also in higher cytotoxicity rates. Furthermore, in collagenous membranes high costs and weak tensile strength in wet conditions show limitations for wide clinical application, resulting in testing of other materials such as silk (16). Lately, coated membranes including magnesium and chitosan or gelatin-chitosan nano-composed membranes have proven biocompatibility, osteogenicconductive potential, and low biodegradation rates $(30,33)$. These new membranes might present excellent alternatives for GBR.

In conclusion, our findings suggested that USSCs can be used for biocompatibility assessment, and moreover, membranes with collagenous composition and porous structure tend to positively impact biocompatibility and enhance cell proliferation. Clinicians should be aware of membrane characteristics and choose a patient-specific membrane when performing GBR.

\section{Conflicts of Interest}

The Authors have no conflicts of interest to declare.

\section{Acknowledgements}

This research did not receive any specific grant from funding agencies in the public, commercial, or not-for-profit sectors.

\section{Authors' Contributions}

Jörg Handschel made substantial contributions to conception and study design; Felix Paulssen von Beck performed the laboratory work. Henrik Holtmann, Julian Lommen and Lara Schorn and analyzed and interpreted the data; Lara Schorn wrote the manuscript. Rita Depprich and Norbert Kübler were involved in revising the manuscript critically. All authors read and approved the final manuscript.

\section{References}

1 Mehl C, Kern M, Freitag-Wolf S, Wolfart M, Brunzel S and Wolfart S: Does the oral health impact profile questionnaire measure dental appearance? Int J Prosthodont 22(1): 87-93, 2009. PMID: 19260435.

2 Meyer U, Meyer T, Handschel $\mathrm{J}$ and Wiesmann HP: Fundamentals of tissue engineering and regenerative medicine. Meyer U, Meyer T, Handschel J and Wiesmann HP (eds.). Springer-Verlag: Heidelberg, Germany, 2009.

3 Papadopulos NA, Schaff J, Sader R, Kovacs L, Deppe H, Kolk A and Biemer E: Mandibular reconstruction with free osteofasciocutaneous fibula flap: A 10 years experience. Injury 39(Suppl 3): S75-82, 2008. PMID: 18703182. DOI: 10.1016/j.injury.2008.05.017

4 Fahmy RA, Mahmoud N, Soliman S, Nouh SR, Cunningham L and El-Ghannam A: Acceleration of alveolar ridge augmentation using a low dose of recombinant human bone morphogenetic protein-2 loaded on a resorbable bioactive ceramic. J Oral Maxillofac Surg 73(12): 2257-2272, 2015. PMID: 26215489. DOI: $10.1016 /$ j.joms.2015.07.004.

5 Lang NP, Hammerle CH, Bragger U, Lehmann B and Nyman SR: Guided tissue regeneration in jawbone defects prior to implant placement. Clin Oral Implants Res 5(2): 92-97, 1994. PMID: 7918914.

6 Schorn L, Sproll C, Ommerborn M, Naujoks C, Kubler NR and Depprich R: Vertical bone regeneration using rhbmp-2 and vegf. Head Face Med 13(1): 11, 2017. PMID: 28592312. DOI: 10.1186/s13005-017-0146-0

7 Buser D, Dula K, Belser U, Hirt HP and Berthold H: Localized ridge augmentation using guided bone regeneration. 1. Surgical procedure in the maxilla. Int J Periodontics Restorative Dent 13(1): 29-45, 1993. PMID: 8330945.

8 Schenk RK, Buser D, Hardwick WR and Dahlin C: Healing pattern of bone regeneration in membrane-protected defects: A histologic study in the canine mandible. Int J Oral Maxillofac Implants 9(1): 13-29, 1994. PMID: 8150509.

9 Gottlow J, Nyman S, Lindhe J, Karring T and Wennstrom J: New attachment formation in the human periodontium by guided tissue regeneration. Case reports. J Clin Periodontol 13(6): 604616, 1986. PMID: 3462208.

10 Hammerle $\mathrm{CH}$ and Karring T: Guided bone regeneration at oral implant sites. Periodontol 2000 17: 151-175, 1998. PMID: 10337322.

11 Schwarz F, Rothamel D, Herten M, Sager M and Becker J: Angiogenesis pattern of native and cross-linked collagen membranes: An immunohistochemical study in the rat. Clin Oral Implants Res 17(4): 403-409, 2006. PMID: 16907771. DOI: 10.1111/j.1600-0501.2005.01225.x

12 Rothamel D, Schwarz F, Sager M, Herten M, Sculean A and Becker J: Biodegradation of differently cross-linked collagen membranes: An experimental study in the rat. Clin Oral Implants Res 16(3): 369-378, 2005. PMID: 15877758. DOI: 10.1111/ j.1600-0501.2005.01108.x

13 Kodama T, Minabe M, Hori T and Watanabe Y: The effect of various concentrations of collagen barrier on periodontal wound healing. J Periodontol 60(4): 205-210, 1989. PMID: 2724034. DOI: $10.1902 /$ jop.1989.60.4.205

14 Cortellini $\mathrm{P}$ and Tonetti MS: Clinical performance of a regenerative strategy for intrabony defects: Scientific evidence and clinical experience. J Periodontol 76(3): 341-350, 2005. PMID: 15857066. DOI: 10.1902/jop.2005.76.3.341 
15 Cortellini P and Tonetti MS: Clinical and radiographic outcomes of the modified minimally invasive surgical technique with and without regenerative materials: A randomized-controlled trial in intra-bony defects. J Clin Periodontol 38(4): 365-373, 2011. PMID: 21303402. DOI: 10.1111/j.1600-051X.2011.01705.x

16 Lee SW and Kim SG: Membranes for the guided bone regeneration. Maxillofac Plast Reconstr Surg 36(6): 239-246, 2014. PMID: 27489841. DOI: 10.14402/jkamprs.2014.36.6.239

17 Kogler G, Sensken S, Airey JA, Trapp T, Muschen M, Feldhahn N, Liedtke S, Sorg RV, Fischer J, Rosenbaum C, Greschat S, Knipper A, Bender J, Degistirici O, Gao J, Caplan AI, Colletti EJ, Almeida-Porada G, Muller HW, Zanjani E and Wernet P: A new human somatic stem cell from placental cord blood with intrinsic pluripotent differentiation potential. J Exp Med 200(2): 123-135, 2004. PMID: 15263023. DOI: 10.1084/jem.20040440

18 Santourlidis S, Wernet P, Ghanjati F, Graffmann N, Springer J, Kriegs C, Zhao X, Brands J, Arauzo-Bravo MJ, Neves R, Koegler $\mathrm{G}$ and Uhrberg M: Unrestricted somatic stem cells (ussc) from human umbilical cord blood display uncommitted epigenetic signatures of the major stem cell pluripotency genes. Stem Cell Res 6(1): 60-69, 2011. PMID: 20933485. DOI: 10.1016/j.scr.2010.08.003

19 Lammers L, Naujoks C, Berr K, Depprich R, Kubler N, Meyer U, Langenbach F, Luttenberg B, Kogler G, Wiesmann HP and Handschel J: Impact of dag stimulation on mineral synthesis, mineral structure and osteogenic differentiation of human cord blood stem cells. Stem Cell Res 8(2): 193-205, 2012. PMID: 22265739. DOI: 10.1016/j.scr.2011.09.004

20 Handschel J, Naujoks C, Langenbach F, Berr K, Depprich RA, Ommerborn MA, Kubler NR, Brinkmann M, Kogler G and Meyer U: Comparison of ectopic bone formation of embryonic stem cells and cord blood stem cells in vivo. Tissue Eng Part A 16(8): 2475-2483, 2010. PMID: 20214449. DOI: 10.1089/ten. TEA.2009.0546

21 Caballe-Serrano J, Munar-Frau A, Ortiz-Puigpelat O, SotoPenaloza D, Penarrocha M and Hernandez-Alfaro F: On the search of the ideal barrier membrane for guided bone regeneration. J Clin Exp Dent 10(5): e477-e483, 2018. PMID: 29849973. DOI: $10.4317 /$ jced.54767

22 Langenbach F, Berr K, Naujoks C, Hassel A, Hentschel M, Depprich R, Kubler NR, Meyer U, Wiesmann HP, Kogler G and Handschel J: Generation and differentiation of microtissues from multipotent precursor cells for use in tissue engineering. Nat Protoc 6(11): 1726-1735, 2011. PMID: 22011655. DOI: 10.1038/ nprot.2011.394

23 Bowers KT, Keller JC, Randolph BA, Wick DG and Michaels $\mathrm{CM}$ : Optimization of surface micromorphology for enhanced osteoblast responses in vitro. Int J Oral Maxillofac Implants 7(3): 302-310, 1992. PMID: 1289255.
24 Wang HL, Miyauchi M and Takata T: Initial attachment of osteoblasts to various guided bone regeneration membranes: An in vitro study. J Periodontal Res 37(5): 340-344, 2002. PMID: 12366856.

25 Rothamel D, Schwarz F, Sculean A, Herten M, Scherbaum W and Becker J: Biocompatibility of various collagen membranes in cultures of human pdl fibroblasts and human osteoblast-like cells. Clin Oral Implants Res 15(4): 443-449, 2004. PMID: 15248879. DOI: 10.1111/j.1600-0501.2004.01039.x

26 Takata T, Wang HL and Miyauchi M: Attachment, proliferation and differentiation of periodontal ligament cells on various guided tissue regeneration membranes. J Periodontal Res 36(5): 322-327, 2001. PMID: 11585120.

27 Speer DP, Chvapil M, Eskelson CD and Ulreich J: Biological effects of residual glutaraldehyde in glutaraldehyde-tanned collagen biomaterials. J Biomed Mater Res 14(6): 753-764, 1980. PMID: 6820019. DOI: 10.1002/jbm.820140607

28 Wiebe D, Megerman J, L'Italien GJ and Abbott WM: Glutaraldehyde release from vascular prostheses of biologic origin. Surgery 104(1): 26-33, 1988. PMID: 3133800.

29 Minguell JJ, Erices A and Conget P: Mesenchymal stem cells. Exp Biol Med (Maywood) 226(6): 507-520, 2001. PMID: 11395921.

30 Acevedo CA, Olguin Y, Briceno M, Forero JC, Osses N, DiazCalderon P, Jaques A and Ortiz R: Design of a biodegradable uvirradiated gelatin-chitosan/nanocomposed membrane with osteogenic ability for application in bone regeneration. Mater Sci Eng C Mater Biol Appl 99: 875-886, 2019. PMID: 30889762. DOI: $10.1016 /$ j.msec.2019.01.135

31 den Braber ET, de Ruijter JE, Smits HT, Ginsel LA, von Recum $\mathrm{AF}$ and Jansen JA: Effect of parallel surface microgrooves and surface energy on cell growth. J Biomed Mater Res 29(4): 511518, 1995. PMID: 7622536. DOI: 10.1002/jbm.820290411.

32 Chehroudi B, McDonnell D and Brunette DM: The effects of micromachined surfaces on formation of bonelike tissue on subcutaneous implants as assessed by radiography and computer image processing. J Biomed Mater Res 34(3): 279-290, 1997. PMID: 9086397

33 Guo Y, Yu Y, Han L, Ma S, Zhao J, Chen H, Yang Z, Zhang F, Xia Y and Zhou Y: Biocompatibility and osteogenic activity of guided bone regeneration membrane based on chitosan-coated magnesium alloy. Mater Sci Eng C Mater Biol Appl 100: 226235, 2019. PMID: 30948056. DOI: 10.1016/j.msec.2019.03.006

Received June 11, 2019

Revised July 10, 2019

Accepted July 19, 2019 